\title{
A new species of Hemibrycon (Teleostei: Characiformes: Characidae) from the río Ucayali drainage, Sierra del Divisor, Peru
}

\author{
Vinicius A. Bertaco*, Luiz R. Malabarba*,**, Max Hidalgo*** and Hernán Ortega***
}

A new characid species, Hemibrycon divisorensis, is described from the río Ucayali drainage, Loreto, Peru. The new species is distinguished from all Hemibrycon species by the presence of a wide black asymmetrical spot covering base of caudal-fin rays and extending along entire length of caudal-fin rays 9 to 12-13 (except from $H$. surinamensis), and a black band in the lower half of the caudal peduncle extending from the region above the last anal-fin rays to the caudal-fin base. Furthermore, it is distinguished from most species of the genus by the number of scale rows below the lateral line (4-5 vs 5-9), except H. jabonero, $H$. microformaa, $H$. orcesi, and H. surinamensis. It differs from these species by scale and fin ray counts and color pattern. The lack of a supraorbital in Hemibrycon species is discussed and confirmed.

Uma nova espécie de caracídeo, Hemibrycon divisorensis, é descrita para a bacia do río Ucayali, Loreto, Peru. A nova espécie distingue-se das demais espécies de Hemibrycon pela presença de uma ampla mancha preta assimétrica na base dos raios da nadadeira caudal estendida até a extremidade dos raios 9 a 12 ou 13 (exceto de H. surinamensis), e de uma faixa preta na metade inferior do pedúnculo caudal desde a região acima dos últimos raios da nadadeira anal até a base da nadadeira caudal. Ela distingue-se da maioria das espécies do gênero pelo número de escamas abaixo da linha lateral (4-5 vs 5-9), exceto de $H$. jabonero, $H$. microformaa, $H$. orcesi e $H$. surinamensis. Ela difere destas espécies pela contagem de escamas, raios das nadadeiras e colorido padrão. Discute-se e confirma-se a ausência do osso supraorbital em Hemibrycon.

Key words: Neotropical, Amazon basin, Taxonomy, Supraorbital, Fin hooks, Carlastyanax.

\section{Introduction}

Hemibrycon is a Neotropical genus of characid fishes which comprises about 21 valid species, occurring in the coastal drainages of the Caribbean sea and East Pacific in Colombia, río Tuira drainage in Panama, rivers drainages in Trinidad and Tobago, río Orinoco and lago Maracaibo in Venezuela, upper río Amazonas in Bolivia, Peru, and Ecuador, and coastal drainages of French Guiana and Suriname (Lima et al., 2003; Román-Valencia \& Ruiz-C., 2007).

The genus Hemibrycon was proposed by Günther (1864), as a subgenus of Tetragonopterus Cuvier, differing by "cleft of the mouth of moderate width, and the entire edge of the maxillary denticulated". Tetragonopterus polyodon Günther was designed as type-species. Hemibrycon was extensively revised by Eigenmann (1927), whose accounts still constitute the single complete review of the genus. Publications on Hemibrycon subsequent to Eigenmann's revision usually in- volves only description of new species occurring in restricted geographic areas of South America.

Eigenmann $(1917,1927)$ further diagnosed Hemibrycon based on the "caudal fin naked, premaxillary with two series of teeth, inner series with four teeth, infraorbital 2 in contact with the lower limb of the preopercle, adipose fin present, anal fin moderate or long, gill-rakers simple, teeth along the greater part or along the entire edge of the maxillary". None of the characters are unique to the genus and most of them are plesiomorphic within Characidae or treated as putative synapomorphies of more inclusive clades containing Hemibrycon (Malabarba \& Weitzman, 2003).

Géry (1966) grouped Hemibrycon along with Boehlkea, Bryconacidnus, Bryconamericus, Ceratobranchia, Coptobrycon, Knodus, Microgenys, Nematobrycon, Piabarchus, Rhinobrycon, and Rhinopetitia, in a new subtribe, Hemibryconini, consisting of a group of Tetragonopterinae with four inner premaxillary teeth, frequently associated with

\footnotetext{
*Museu de Ciências e Tecnologia, Pontifícia Universidade Católica do Rio Grande do Sul, Av. Ipiranga 6681, 90619-900 Porto Alegre, RS, Brazil. ubertaco@pucrs.br

**Departamento de Zoologia, IB, Universidade Federal do Rio Grande do Sul, Av. Bento Gonçalves, 9500, 91501-970 Porto Alegre, RS, Brazil.malabarb@ufrgs.br

***Departamento de Ictiologia, Museo de Historia Natural, Universidad Nacional Mayor de San Marcos, PO Box 14-0434, Lima - 14, Peru.maxhhidalgo@yahoo.com, tortegat@unmsm.edu.pe
} 
a great development of the third infraorbital, and, quite often, the irregular implantation of the outer premaxillary row of teeth. Malabarba \& Weitzman (2003) recognized Hemibrycon as belonging to a large monophyletic clade inside Characidae (therein named Clade A), based on the putative derived presence of four teeth in the inner series of the premaxilla and reduced number of dorsal-fin rays (ii,8). Additionally, they considered Hemibrycon and Boehlkea as apparently the most basal genera in that clade, by lacking all specializations related to insemination, development of caudal- and/or anal-fin glands or the jaw and teeth modifications related to the ventral position of the mouth, as observed in the remaining genera and species of Clade A.

During a recent expedition to the Zona Reservada Sierra del Divisor, Peru, a new species of Hemibrycon was collected in the río Ucayali drainage and it is herein described. This is part of a systematic study of Hemibrycon conducted by the senior author (doctoral thesis).

\section{Materials and Methods}

Counts were taken as described by Fink \& Weitzman (1974), with the exception of number of scale rows below lateral line which were counted from the scale row ventral to lateral line to the scale row nearest the first pelvic-fin ray. Vertebral counts, supraneurals, gill-rakers, teeth, and procurrent caudal-fin-ray counts were taken from cleared and stained specimens (c\&s) prepared according to the method of Taylor \& Van Dyke (1985). The gill raker at the junction of the ceratobranchial and the epibranquial is included in the counting of gill rakers of lower limb. Maxillary tooth counts were taken in type specimens included in Table 1. Counts for the holotype are indicated with an asterisk. Vertebral counts include the four vertebrae integrated in the Weberian apparatus and the terminal centrum was counted as one vertebra. Scanning electron micrographs (SEM) of teeth and jaws were taken from one cleared and stained dissected specimen. Testes were removed prior to clearing and staining, dehydrated in an ethanol series until $99.5 \%$, and critical point dried. The dried testes were placed in stub with carbon tape and split with a needle, coated with gold and carbon, and viewed with SEM.

Measurements were taken point to point with an electronic caliper from the left side of the specimens. All measurements other than SL are expressed as a percents of SL except subunits of the head, which are recorded as a percents of head length (HL).

Specimens examined belong to the following institutions: ANSP, Academy of Natural Sciences, Philadelphia; BMNH, Natural History Museum, London; CAS, California Academy of Sciences, San Francisco; FMNH, Field Museum of Natural History, Chicago; IAvH-P, Instituto Alexander von Humboldt - Peces, Villa de Leyva; IMCN, Colección Zoológica de Referencia del Museo Departamental de Ciencias Naturales Federico Carlos Lehmann Valencia - INCIVA, Valle del Cauca, Cali; MCP, Museu de Ciências e Tecnologia, Pontifícia
Universidade Católica do Rio Grande do Sul, Porto Alegre; MHNG, Muséum d'historie naturelle, Geneva; MNHN, Muséum nationale d'historie naturelle, Paris; MUSM, Museo de Historia Natural de la Universidad Nacional Mayor de San Marcos, Lima; NMW, Naturhistorisches Museum, Wien; USNM, National Museum of Natural History, Washington D.C.; ZMA, Universitat van Amsterdam Zoologisch Museum, Amsterdam; and ZMUC, Zoological Museum, University of Copenhagen, Copenhagen.

\section{Hemibrycon divisorensis, new species}

Figs. 1-3

Holotype. MUSM 28860, $68.2 \mathrm{~mm}$ SL, male, Peru, Loreto, Requena, Zona Reservada Sierra del Divisor, upper río Tapiche, quebrada en la trocha 1 , río Ucayali drainage, $07^{\circ} 12^{\prime} 02^{\prime \prime S}$ 7353'00"W, 20 Aug 2005, M. Hidalgo \& J. F. P. da Silva.

Paratypes. MCP 41346, 4 (60.5-81.6 mm SL), 2 c\&s (62.7-68.4 mm SL), MUSM 28040, 19, 35.0-73.0 mm SL, collected with holotype. MCP 41347, 5, 48.9-65.0 mm SL, MUSM 28039, 11 (43.0$58.0 \mathrm{~mm} \mathrm{SL}), 1$ c\&s (55.9 mm SL), Peru, Loreto, Zona Reservada Sierra del Divisor, Ojo de Contaya, quebrada en la trocha 4, río Ucayali drainage, $07^{\circ} 06^{\prime} 54^{\prime \prime S} 74^{\circ} 35^{\prime} 08^{\prime \prime} \mathrm{W}, 6$ Aug 2005, M. Hidalgo \& J. F. P. da Silva.

Diagnosis. Hemibrycon divisorensis is distinguished from all other species of the genus by the presence of a wide black asymmetrical spot covering the base of caudal-fin rays and extending along entire length of caudal-fin rays 9 to 12-13 (except from $H$. surinamensis), and by the presence of a black band in the lower half of the caudal peduncle from the region above the last anal-fin rays to the caudal-fin base (Figs. 1-2). Furthermore, it is distinguished from most species of the genus by the number of the scale rows below lateral line (4-5vs 5-9), except from H. jabonero, H. microformaa, H. orcesi, and $H$. surinamensis. Hemibrycon divisorensis differs from $H$. orcesi and $H$. microformaa by the higher number of lateral line scales (39-42 vs 34-35 and 33-37, respectively) and analfin rays (24-30 vs 18 and 14-16, respectively), and by color pattern; from $H$. jabonero and $H$. surinamensis by the higher number of scale sheath along anal-fin base (17-22 vs 8-14 and 15-16, respectively), and number of cusps in the inner row of the premaxilla teeth (5-7 vs 5, respectively).

Description. Morphometric data for Hemibrycon divisorensis summarized in Table 1. Largest male $68.4 \mathrm{~mm} \mathrm{SL}$, largest female $81.6 \mathrm{~mm}$ SL. Body compressed and moderately elongate; greatest body depth usually nearly to dorsal-fin origin. Dorsal profile of head slightly convex to nearly straight. Dorsal body profile slightly convex from supraoccipital to dorsal-fin origin; posteroventrally slanted from dorsal-fin origin to adipose fin. Ventral profile of head slightly convex. Ventral body profile convex from isthmus to pelvic-fin origin, and straight to slightly convex from this point to anal-fin origin. Body profile along anal-fin base posterodorsally slanted. Caudal peduncle slightly concave along dorsal and ventral margins. 


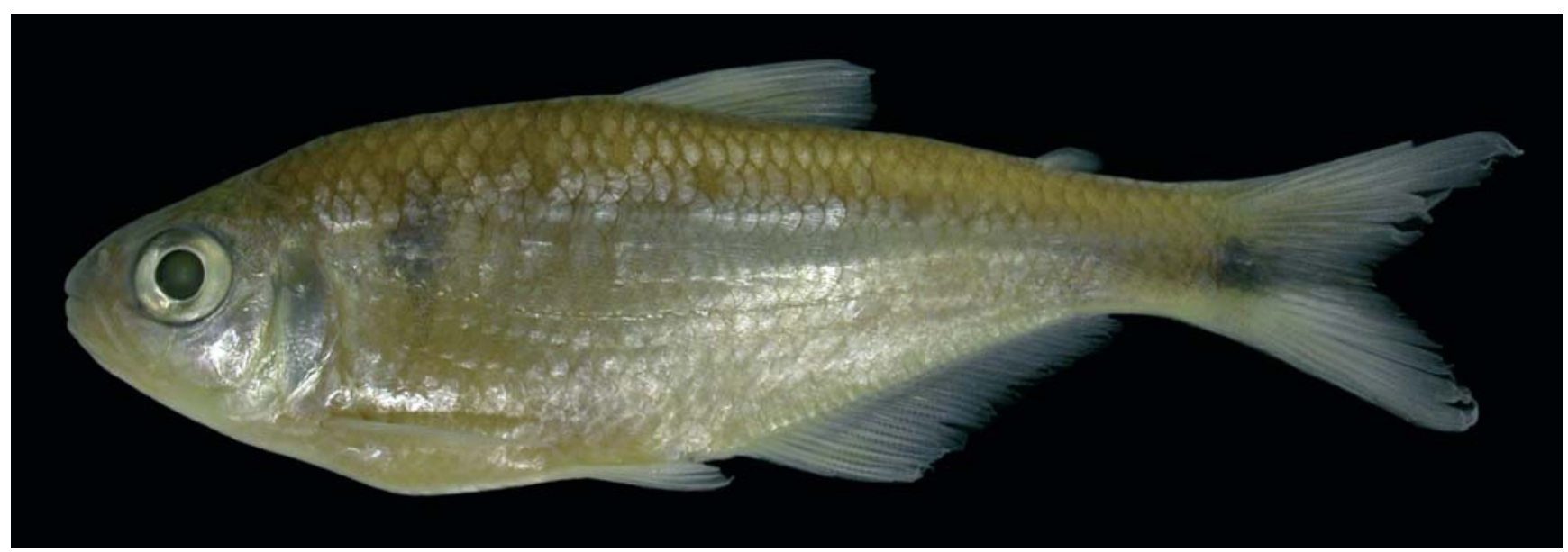

Fig. 1. Hemibrycon divisorensis, MUSM 28860, holotype, male, $68.2 \mathrm{~mm}$ SL; río Ucayali drainage, Loreto, Peru.

Snout rounded from margin of upper lip to vertical through anterior nostrils. Head small. Mouth terminal, mouth slit nearly at horizontal through middle of eye. Maxilla long, slightly curved, and aligned at angle of approximately 60 degrees to longitudinal body axis, with ventral border slightly convex to nearly straight and dorsal border slightly concave.

Premaxilla with two tooth rows; outer row teeth 4-7 (6*), tricuspid to pentacuspid, central cusp slightly longer; inner row teeth 4 , pentacuspid to heptacuspid, central cusp twice or three times longer and broader than other cusps, gradually decreasing in length from first to third teeth and last tooth smallest. Maxilla fully toothed with 10-13 (11*) tricuspid teeth with central cusp longer, except for last six or seven conical teeth. Three anteriormost dentary teeth larger, with 5-7 cusps, followed by medium sized tooth with 3-5 cusps, and 9-12 teeth with 2-3 cusps or conical; central cusp in all teeth two to three times longer and broader than other cusps (Fig. 3). All cusp tips slightly curved posteriorly towards inside of mouth.

Dorsal-fin rays ii,8 $(n=19)$; first unbranched ray approximately one-half length of second ray. Dorsal-fin origin located slightly posterior to middle of SL and posterior to vertical through pelvic-fin origin. First dorsal-fin pterygiophore inserted between neural spines of $11^{\text {th }}$ to $12^{\text {th }}$ vertebrae $(\mathrm{n}=3)$. Profile of distal margin of dorsal fin slightly concave or nearly straight. Males with bony hooks on distal one-third of first to fifth branched dorsal-fin rays. Adipose-fin located approximately at vertical through insertion of last four or five anal-fin rays.

Anal-fin rays iv, $25-28\left(27^{*}\right.$, rarely 24 or $29-30$, mean $=26.7$, $\mathrm{n}=19$ ). Anal-fin profile nearly straight in males and concave in females. Anal-fin origin approximately at vertical through insertion of last two or three dorsal-fin rays. First anal-fin pterygiophore inserted between hemal spines of first and second caudal vertebrae. Anal-fin rays of males bearing one pair of small bony hooks along posterolateral border of each segment of lepidotrichia, usually along first to $12^{\text {th }}$ anterior branched rays. Hooks more numerous along fourth through seventh branched rays, and usually located along posteriormost branch and distal $1 / 2$ to $2 / 3$ of each ray.

Pectoral-fin rays i,10-13 $\left(11^{*}\right.$, mean $\left.=11 \cdot 1, \mathrm{n}=19\right)$. Pecto- ral-fin tip reaching pelvic-fin origin in males, not in females. Males with bony hooks on distal portion of unbranched and all branched pectoral-fin rays. Pelvic-fin rays i,6,i $(n=11)$ or $\mathrm{i}, 7^{*}(\mathrm{n}=8)$. Pelvic-fin origin located at vertical through 3-4 predorsal scales anterior to dorsal-fin origin. Pelvic fin of males usually bearing one small bony hook per lepidotrichia segment along ventromedial border of all branched rays.

Caudal fin forked with 19 principal rays $(n=19)$; lobes similar in size. Basal portion of caudal-fin lobes covered with somewhat irregular scales and smaller than those of body, following by one larger and round shaped scale in each lobe. Dorsal procurrent rays 11 and ventral procurrent rays 10-11 $(\mathrm{n}=3)$.

Scales cycloid, moderately large. Lateral line complete with $39-41$ scales $\left(41^{*}\right.$, one specimen with 42 , mean $\left.=40.2, n=19\right)$. Scale rows between dorsal-fin origin and lateral line 6-7 (6*, mean $=6.5, \mathrm{n}=19)$; scale rows between lateral line and pelvicfin origin 4-5 $\left(5^{*}\right.$, mean $\left.=4.7, \mathrm{n}=19\right)$. Predorsal scales $13-15$, arranged in regular series $\left(13^{*}\right.$, mean $\left.=13.3, \mathrm{n}=19\right)$. Scale rows around caudal peduncle 14-16 $\left(14^{*}\right.$, mean $\left.=15.5, \mathrm{n}=19\right)$. Triangular modified scale on pelvic-fin origin posteriorly covering three scales. Scale sheath along anal-fin base with 17$22\left(18^{*}\right)$ scales in single series, extending to base of $18^{\text {th }}$ to $20^{\text {th }}$ branched rays.

Precaudal vertebrae 16-17; caudal vertebrae 21-22; total vertebrae 38-39. Supraneurals 5-6 $(n=3)$. Gill-rakers on upper limb of outer gill arch 7-9, and on lower limb 12-14 $(n=8)$.

Color in alcohol. General body color yellowish to yellowishbrown. Dorsal and dorsolateral portions of head and body pigmented dark brown. Dorsolateral portion of body with scales bordered by dark pigment and forming reticulate pattern. One black humeral spot vertically elongate, wide in dorsal portion and narrowing ventrally; wide dorsal portion of humeral spot located over two or three scales of two scale series just above lateral line; narrow portion crossing lateral line at fourth and/or fifth scales and extending one or two scale series just below lateral line. Midlateral body silvery. Lower half portion of caudal peduncle from region above last anal-fin rays to caudal-fin base black pigmented, usually from 


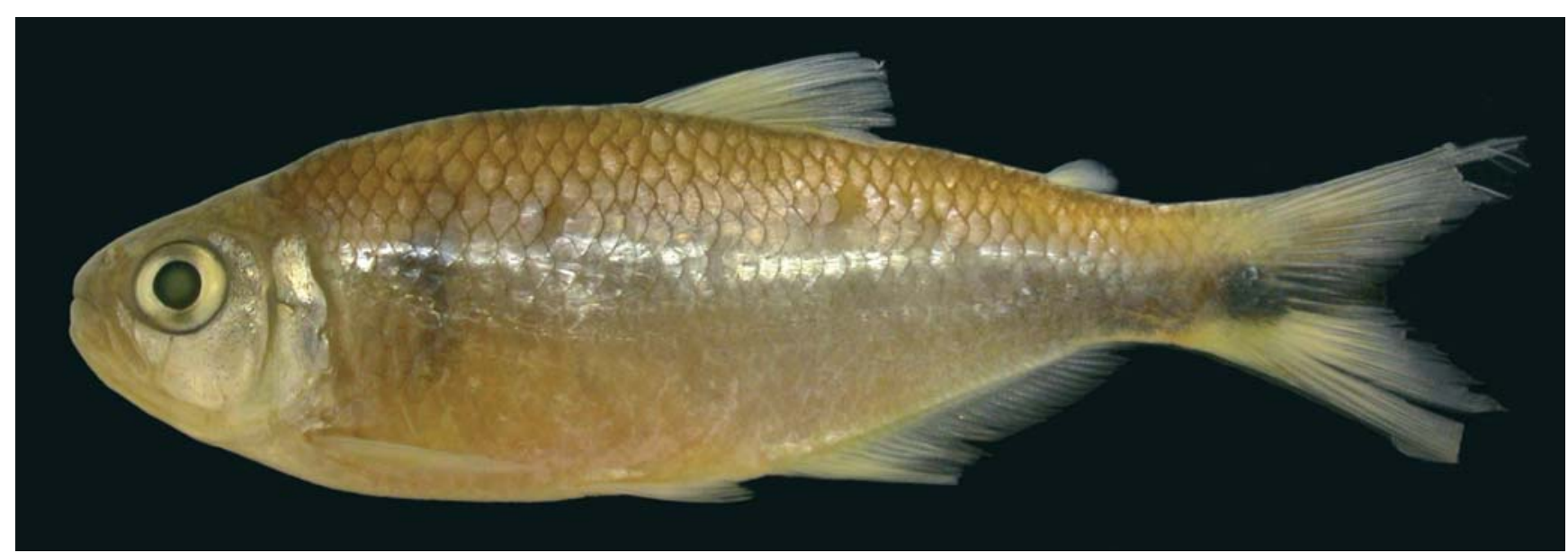

Fig. 2. Hemibrycon divisorensis, MCP 41346, paratype, female, 81.6 mm SL; río Ucayali drainage, Loreto, Peru.

the scale row bearing the lateral line to the scales near analfin base and ventral margin of caudal peduncle. Wide and asymmetric black spot covering base of middle caudal-fin rays and extending along entire length of caudal-fin rays 9 to 12-13. Dorsal and caudal fin with dark pigmentation diffuse. Anal fin with small black chromatophores along its border forming narrow stripe. Other fins without distinctive marks (Figs. 1-2).

Color just after fixation. Color pattern similar to described for alcohol preserved specimens. Specimens examined soon after fixation in formalin with dorsal and adipose fins and caudal peduncle reddish pigmented, and red spot on ventral portion of caudal-fin base.

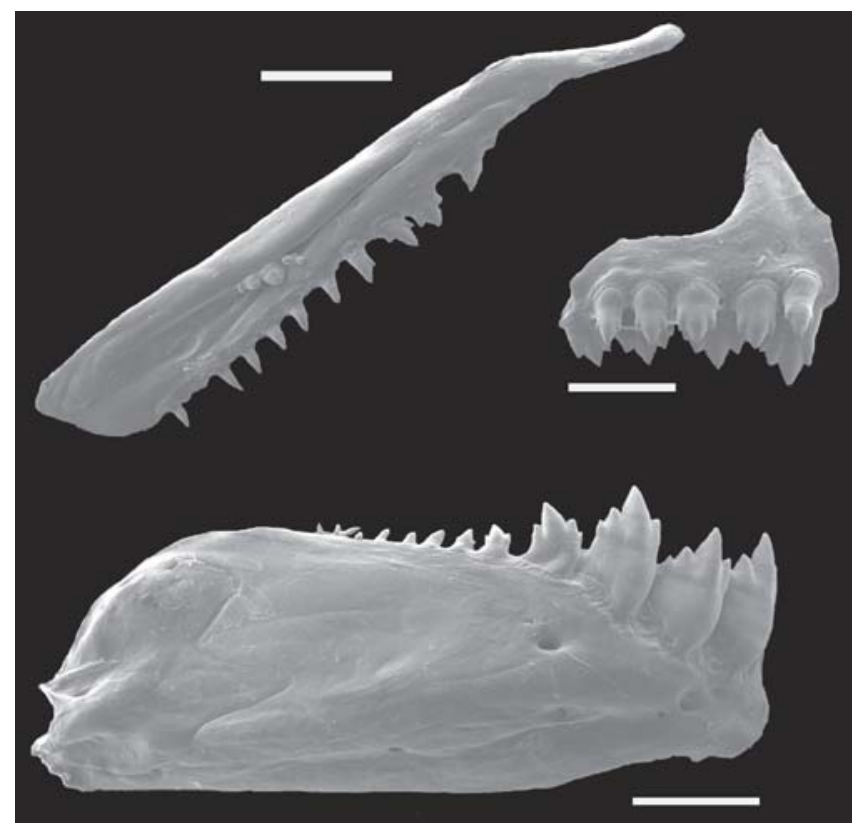

Fig. 3. Hemibrycon divisorensis, MCP 41346, paratype, male, $68.4 \mathrm{~mm}$ SL. Scanning electron micrograph of right side upper and lower jaws. The presence of 3-4 teeth in the midlateral of maxilla is an anomaly. Scale bar $=1 \mathrm{~mm}$.
Sexual dimorphism. Males of Hemibrycon divisorensis are easily recognized by the presence of small bony hooks on the dorsal-, anal-, pelvic-, and pectoral-fin rays (see Description). Also, males and females differ in pectoral and pelvic-fin lengths (Table 1), and anal-fin shape, which is nearly straight in males and concave in females (Figs. 1-2). Mature males do not present gill gland on first arch.

Distribution. Hemibrycon divisorensis is known only from the río Tapiche drainage, a tributary to the río Ucayali, Loreto, Peru. This locality is included in the conservation area "Zona Reservada Sierra del Divisor" recently established by the Peruvian government.

Table 1. Morphometric data of holotype (MCP 28860, male) and paratypes (6 of MCP 41346, 5 of MCP 41347, 4 of MUSM 28039, and 3 of MUSM 28040) of Hemibrycon divisorensis from the río Ucayali drainage, Loreto, Peru. The range includes the holotype. $m$, males $(n=6)$; f, females $(n=13) . S D=$ standard deviation.

\begin{tabular}{lcccc}
\hline & Holotype & Range & Mean & SD \\
\hline Standard length (mm) & 68.2 & $48.9-81.6$ & - & - \\
& Percents of standard length & & \\
Predorsal distance & 50.2 & $49.8-55.5$ & 51.5 & 1.21 \\
Prepelvic distance & 43.6 & $43.6-47.6$ & 45.4 & 0.95 \\
Prepectoral distance & 24.4 & $23.6-26.0$ & 24.9 & 0.64 \\
Preanal distance & 59.3 & $59.3-63.6$ & 61.2 & 1.27 \\
Depth at dorsal-fin origin & 33.0 & $32.9-36.2$ & 34.3 & 1.09 \\
Caudal peduncle depth & 11.3 & $10.7-12.2$ & 11.8 & 0.44 \\
Caudal peduncle length & 13.8 & $11.7-13.8$ & 13.0 & 0.65 \\
Anal-fin base & 32.7 & $29.6-32.9$ & 31.5 & 0.95 \\
Dorsal-fin length & 23.2 & $22.9-25.9$ & 23.9 & 0.77 \\
Pelvic-fin length (m) & 16.4 & $15.9-17.1$ & 16.4 & 0.45 \\
Pelvic-fin length (f) & - & $13.7-15.7$ & 14.8 & 0.63 \\
Pectoral-fin length (m) & 21.1 & $20.6-22.9$ & 21.7 & 0.79 \\
Pectoral-fin length (f) & - & $19.1-21.4$ & 20.4 & 0.74 \\
Head length & 23.8 & $22.6-24.9$ & 24.0 & 0.55 \\
& Percents of head length & & \\
Snout length & 24.7 & $22.4-24.7$ & 23.3 & 0.61 \\
Upper jaw length & 43.8 & $43.8-47.7$ & 45.8 & 0.97 \\
Orbital diameter & 34.6 & $31.7-35.5$ & 33.8 & 1.28 \\
Interorbital width & 33.8 & $32.2-36.6$ & 34.4 & 1.26 \\
\hline
\end{tabular}


Etymology. The species name, divisorensis, is in reference to the type locality. A noun in apposition.

Ecological notes. The tributaries of río Tapiche where the type specimens were collected are about 2-3 m wide with crystalline water, $0.3-0.5 \mathrm{~m}$ deep, medium water current, sandy substrate, and with moderate amount of riparian vegetation.

Spermatozoa. Hemibrycon divisorensis has a typical aquasperm with a spherical to slightly ovoid nucleus (MCP $28040,62.7 \mathrm{~mm} \mathrm{SL}$ ), suggesting that the species is non-inseminating (Burns et al., 1995, 1998; Burns \& Weitzman, 2005). Due to the lack of mature females, it was not possible to verify the presence of spermatozoa in the ovaries of $H$. divisorensis.

\section{Discussion}

The new species is described in Hemibrycon considering the definition of the genus currently in use, proposed by Günther (1864) and further elaborated by Eigenmann (1927). The systematics of Hemibrycon is still unresolved and the genus lacks a phylogenetic diagnosis. Eigenmann (1917) distinguished Hemibrycon from Bryconamericus only by the "few teeth along the upper portion of the maxillary" in the latter, compared to the large toothed maxilla of the former. Román-Valencia (2000) considered Hemibrycon related to Bryconamericus, but did not present a phylogenetic evidence to support his hypothesis.

Recently, Malabarba \& Weitzman (2003) recognized a putative monophyletic clade within Characidae, which includes Hemibrycon, along with the subfamily Glandulocaudinae (now Glandulocaudinae and Stevardiinae) and the genera Attonitus Vari \& Ortega, Boehlkea Géry, Bryconacidnus Myers, Bryconamericus Eigenmann, Caiapobrycon Malabarba \& Vari, Ceratobranchia Eigenmann, Creagrutus Günther, Cyanocharax Malabarba \& Weitzman, Hypobrycon Malabarba \& Malabarba, Knodus Eigenmann, Microgenys Eigenmann, Monotocheirodon Eigenmann \& Pearson, Odontostoechus Gomes, Othonocheirodus Myers, Piabarchus Myers, Piabina Reinhardt, Rhinobrycon Myers, and Rhinopetitia Géry. Additionally, Hemibrycon and Boehlkea were considered as apparently the most basal genera in that clade, by lacking all specializations related to insemination, development of caudal and/or anal glands, or the jaw and teeth modifications related to ventral mouth, as observed in the species of the remaining genera of that clade. The species of Hemibrycon further differ from the species of all those genera by sharing a large number of teeth in the maxilla, as observed in the new species described herein. A taxonomic review and phylogenetic analysis of Hemibrycon species is in progress by the senior author, and evaluates the potential use of this and other characters in defining Hemibrycon.

Weitzman et al. (2005: 344$)$ suggest that detailed investigations of the histology and ultrastructure of sperm cells is necessary for a useful evaluation of the phylogenetic significance of insemination in characids included in Clade A. We agree with that, but testes properly fixed for Transmission Electronic Microscopy (TEM) analyses of the ultrastructure of sperm cells and mature ovaries for histological examination were not available. We have made SEM preparations of testes and found $H$. divisorensis has a typical aquasperm with a spherical to slightly ovoid nucleus suggesting the species is not inseminating.

According to Román-Valencia \& Ruiz-C. (2007), a supraorbital bone is found in H. boquiae, H. microformaa, H. orcesi, $H$. pautensis, and $H$. polyodon, and its presence would not support the inclusion of Hemibrycon among Clade A genera of Malabarba \& Weitzman (2003). The supraorbital, however, is absent in all species of Hemibrycon examined by one of us (VAB). The supraorbital is also described by Ruiz-C. \& RománValencia (2006:51) in Carlastyanax aurocaudatus as [our translation]: long and narrow, joined laterally to the frontal, with anterior and posterior tips semi-concave and originating the supraorbital canal, flattened dorsal surface. The anteroventral surface of the supraorbital articulates to the dorsal portion of the lateral ethmoid through a band of cartilage extending from the joining of frontal and orbitosphenoid ["hueso largo, angosto, unido lateralmente al frontal, cuyos extremos anterior y posterior semicóncavos dan lugar al canal supraorbital, superficie dorsal más plana. La superficie anteroventral del supraorbital se articula a la parte dorsal del lateroetmoide, mediante una banda de cartílago que se extiende entre la unión del frontal y el orbitoesfenoide"]. This description corresponds to the lateralmost laminar portion of the frontal, external to the laterosensory tube that runs dorsally in the frontal. In the same paper (p.61), the supraorbital is described as an element joined to the lateral border of the frontal originating the laterosensory canal that continues in the nasal ["una estructura ...., que al unirse al borde lateral del frontal da origin al canal laterosensorial, que se continúa con el nasal"]. The only representation of the supraorbital bone is given in a superficial sketch of a dorsal view of the skull of Carlastyanax aurocaudatus (Ruiz-C. \& Román-Valencia, 2006:50, fig. 1), and it is shown in the same position of the lateral expansion of the frontal, external to the lateral line canal of this bone. Apparently, Ruiz-C. \& RománValencia (2006) assumed that the laterosensory tube that runs dorsally and divides the frontal is the limit between the frontal and the ossification they interpret as a supraorbital. We have examined cleared and stained specimens of Carlastyanax aurocaudatus and a supraorbital is absent, likewise in the examined species of Hemibrycon.

Hemibrycon divisorensis possess a wide black asymmetrical spot covering the base of caudal-fin rays and extending to the tip of median caudal-fin rays, and a black band in the lower half of caudal peduncle from above of last anal-fin rays to caudal fin base, characters uncommon among the species of the genus. Among Hemibrycon species a black asymmetrical spot covering base of caudal-fin rays is found only in $H$. surinamensis, but black band in the lower half of caudal pe- 
duncle is unique to $H$. divisorensis, here considered an autapomorphy to the species. All other Hemibrycon species have a dark midlateral body stripe extending to the tip of median caudal-fin rays, or have only the median caudal-fin rays symmetrically pigmented.

Mature males of Hemibrycon divisorensis possess bony hooks on rays of all fins, except the caudal fin. The presence of hooks on the anal- and pelvic-fin rays and sometime caudal-fin rays of males is often found in several genera and subfamilies of the Characidae (Azpelicueta \& Garcia, 2000; Malabarba \& Weitzman, 2003), and usually represents a secondary sexual character. However, the occurrence of bony hooks in all fins, including dorsal, caudal, and pectoral fins of males is uncommon in characids. Recently, Gonçalves et al. (2005) observed a positive correlation between mean gonadosomatic index of maturing and mature males and the number of anal-fin rays bearing hooks in Aphyocharax anisitsi, suggesting these hooks develop along with testes maturation, and once developed are retained by the males.

Recently some species of Tetragonopterinae (sensu Géry) have been described with bony hooks on rays of all fins in males, e.g. Moenkhausia pankilopteryx, and except in the caudal fin in Astyanax elachylepis and Hyphessobrycon hamatus (see Bertaco \& Malabarba, 2005). The presence of bony hooks on the dorsal- and pectoral-fin rays is unknown among the species of Hemibrycon.

Four species of Hemibrycon were described from the upper río Amazonas drainage in Peru: H. jelskii (Steindachner, 1877), H. helleri Eigenmann (1927), and H. tridens Eigenmann (1922) from río Ucayali drainage, and H. huambonicus (Steindachner, 1882) from río Huallaga drainage. Hemibrycon divisorensis differs from all these species by the number of branched anal-fin rays, number of scale rows above and below the lateral line, and number of lateral line scales.

Comparative material. Astyanax aurocaudatus, CAS 68647, 5 paratypes, río Cauca basin, Boquia, Quindio, Colombia. Bryconamericus decurrens, CAS 39542, paratype, town on the Dique de Cartagena between Cartagena and Calamar, Soplaviento, Bolivar, Colombia. Bryconamericus tolimae, FMNH 56258, 7 paratypes, río Magdalena drainage, Ibagué, Colombia. Carlastyanax aurocaudatus, IMCN 891, 8, río Quindio, Armenia, Colombia; MCP 41717, 4+2 c\&s, río Cauca basin, Cauca, Colombia. Hemibrycon beni, CAS 44333, 29 syntypes, río Beni drainage, Espia, La Paz, Bolivia. Hemibrycon boquiae, FMNH 56260, 10 paratypes, Boquia, Colombia. Hemibrycon carrilloi, IAvH-P 7156, 22, río El Tigre, Unguia, río Atrato basin, Chocó, Colombia. Hemibrycon colombianus, CAS 44353, 5 paratypes, río Magdalena drainage, Quebrada Mararari, Santander, Colombia. Hemibrycon dariensis, USNM 78594, 8 paratypes, río Yape, Darien, Panama. Hemibrycon helleri, CAS 44354, 5 paratypes, río Comberciato, tributary of middle río Urubamba, Cuzco, Peru. Hemibrycon jabonero, USNM 121456, 601 paratypes, río Gonzáles, tributary of río Chama at La Gonzáles, Mérida, Venezuela. Hemibrycon metae, CAS 123727, holotype, at junction of río Guavio and río Upia, río Meta drainage, Guaiacaramo, Colombia. Hemibrycon orcesi, ANSP 75904, 2 paratypes, headwaters of río Macuma, tributary of río Morona, Ecuador. Hemibrycon surinamensis, MHNG 2182.59, 2 paratypes, brownskreek sur 114 km railroad Paramacca River drainage, Suriname. MNHN 1980.1435, 1 paratype, Suriname. ZMA 100.347, 4 of 7 paratypes, Paramacca River drainage, brownscreek, km 14 of the railroad Paramaribo-Dam, Suriname. Hemibrycon tridens, CAS 44358, holotype, 24 leagues from Cuzco, Curuhuasi, Peru. Tetragonopterus guppyi, BMNH 1906.6.23.13-17, 5 syntypes, Trinidad. Tetragonopterus huambonicus, NMW 57531, syntype, Huambo, Peru. Tetragonopterus jelskii, NMW 57554, 5 syntypes, Huambo, Huánuco, Peru. Tetragonopterus polyodon, BMNH 1858.7.25.41, holotype, Guayaquil, Ecuador. Poecilurichthys taeniurus, ZMUC 966-968, 3 syntypes, Trinidad Island.

\section{Acknowledgments}

We are grateful to John Lundberg and Mark Sabaj (ANSP), David Catania (CAS), Mary Anne Rogers (FMNH), Sonia Fisch-Muller (MHNG), Guy Duhamel and Patrice Pruvost (MNHN), Helmut Wellendorf and Ernst Mikschi (NMW), Stanley Weitzman and Sandra Raredon (USNM), Isaäc Isbrücker (ZMA), Jorgen Nielsen (ZMUC) for selection and loan of specimens; to Roberto Reis and Tiago Carvalho (MCP) by the examination of the types of $H$. polyodon and $H$. guppyi at BMNH; to Javier Maldonado by assistance in the Instituto Alexander von Humboldt; to Carlos Santana by assistance in the radiograph's while at the USNM; to the Centro de Microscopia e Microanálises-CEMM, PUCRS for the SEM preparations. Specimens were collected during an expedition supported by the Nature Conservancy, the Field Museum of Natural History, and Fundación Peruana para la Conservación de la Naturaleza. Thanks to José P. da Silva for photographs taken just after fixation of specimens. This paper benefited from comments and criticisms by two anonymous reviewers. We are grateful to Monica T. Piza-Ragazzo by the discussions related to the supraorbital bone. VAB is grateful by the Fellowships offered by the Academy of Natural Sciences, California Academy of Sciences, Field Museum of Natural History, Muséum d'historie naturelle, Geneva, and National Museum of Natural History, Smithsonian Institution, and is financially supported by the Coordenação de Aperfeiçoamento de Pessoal de Nível Superior (CAPES). Financial support was provided by CNPq (Proc. 464545/00-5; 478002/2006-8).

\section{Literature Cited}

Azpelicueta, M. M. \& J. O. Garcia. 2000. A new species of Astyanax (Characiformes, Characidae) from Uruguay river basin in Argentina, with remarks on hook presence in Characidae. Revue Suisse de Zoologie, 107(2): 245-257.

Bertaco, V. A. \& L. R. Malabarba. 2005. A new species of Hyphessobrycon (Teleostei: Characidae) from the upper rio Tocantins drainage, with bony hooks on fins. Neotropical Ichthyology, 3(1): 83-88.

Burns, J. R., S. H. Weitzman, H. J. Grier \& N. A. Menezes. 1995. Internal fertilization, testis and sperm morphology in glandulocaudine fishes (Teleostei: Characidae: Glandulocaudinae). Journal of Morphology, 224: 131-145.

Burns, J. R., S. H. Weitzman, K. R. Lange \& L. R. Malabarba. 1998. 
Sperm ultrastructure in Characid fishes (Teleostei: Ostariophysi). Pp. 235-244. In.: Malabarba, L. R., R. E. Reis, R. P. Vari, Z. M. S. Lucena \& C. A. S. Lucena (Eds.). Phylogeny and Classification of Neotropical Fishes. Porto Alegre, Edipucrs, 603p.

Burns, J. R. \& Weitzman, S. H. 2005. Insemination in Ostariophysan fishes. Pp. 107-134. In: Grier, H. J. \& M. C. Uribe (Eds.). Viviparous Fishes. New Life Publications, Homestead Florida.

Eigenmann, C. H. 1917. The American Characidae. Part 1. Memoirs of the Museum of Comparative Zoology, 43(1): 1-102.

Eigenmann, C. H. 1927. The American Characidae. Part 4. Memoirs of the Museum of Comparative Zoology, 43(4): 311-428.

Fink, W. L. \& S. H. Weitzman. 1974. The so-called cheirodontin fishes of Central America with descriptions of two new species (Pisces: Characidae). Smithsonian Contributions to Zoology, 172: 1-46.

Géry, J. 1966. A review of certain Tetragonopterinae (Characoidei), with the description of two new genera. Ichthyological Aquarium Journal, 37: 211-236.

Gonçalves, T. K., M. A. Azevedo, L. R. Malabarba \& C. B. Fialho. 2005. Reproductive biology and development sexually dimorphic structures in Aphyocharax anisitsi (Ostariophysi: Characidae). Neotropical Ichthyology, 3(3): 433-438.

Günther, A. 1864. Catalogue of the fishes in the British Museum. Catalogue of the Physostomi, containing the families Siluridae, Characinidae, Haplochitonidae, Sternoptychidae, Scopelidae, Stomiatidae in the collection of the British Museum. Catalogue Fishes, 5: 1-455.

Lima, F. C. T, L. R. Malabarba, P. A. Buckup, J. F. Pezzi da Silva, R. P. Vari, A. Harold, R. Benine, O. T. Oyakawa, C. S. Pavanelli, N. A. Menezes, C. A. S. Lucena, M. C. S. L. Malabarba, Z. M. S. Lucena, R. E. Reis, F. Langeani, L. Casatti, V. A. Bertaco, C. Moreira \& P. H. F. Lucinda. 2003. Genera incertae sedis in Characidae. Pp. 134-141. In: R. E. Reis, S. O. Kullander \& C. J. Ferraris (Eds.). Check List of the Freshwater Fishes of South and Central America. Porto Alegre, Edipucrs, 729p.
Malabarba, L. R. \& S. H. Weitzman. 2003. Description of new genus with six new species from southern Brazil, Uruguay and Argentina, with a discussion of a putative characid clade (Teleostei: Characiformes: Characidae). Comunicações do Museu de Ciências e Tecnologia da PUCRS, Série Zoologia, 16(1): 67-151.

Román-Valencia, C. 2000. Tres nuevas especies de Bryconamericus (Ostariophysi: Characidae) de Colombia y diagnóstico del género. Revista de Biología Tropical, 48(2/3): 449-464.

Román-Valencia, C. \& R. I. Ruiz-C. 2007. Una nueva especie de pez del género Hemibrycon (Characiformes: Characidae) del alto río Atrato, noroccidente de Colombia. Caldasia, 29(1): 121131.

Ruiz-C., R. I. \& C. Román-Valencia. 2006. Osteología de Astyanax aurocaudatus Eigenmann, 1913 (Pisces, Characidae), con notas sobre la validez de Carlastyanax Géry, 1972. Animal Biodiversity and Conservation, 29(1): 49-64.

Taylor, W. R. \& G. C. Van Dyke. 1985. Revised procedures for staining and clearing small fishes and other vertebrates for bone and cartilage study. Cybium, 9: 107-119.

Weitzman, S. H., N. A. Menezes, H. G. Evers \& J. R. Burns. 2005. Putative relationships among inseminating and externally fertilizing characids, with a description of a new genus and species of Brazilian inseminating fish bearing an anal-fin gland in males (Characiformes: Characidae). Neotropical Ichthyology, 3(3): 329-360.

Submitted May 2007 Accepted August 2007 